\title{
透析患者における整形外科手術の問題点
}

\author{
社会保険中京病院整形外科 \\ 鈴木潔・服 部 祥 明 \\ 山田順亮・小西陽一
}

\section{Orthopedic Surgery for Chronic Hemodialysis Patients}

by

\section{Kiyoshi Suzuki, Yoshiaki Hattori, Yoshiaki Yamada and Yoichi Konishi}

Department of Orthopedic Surgery, Chukyo Hospital, Nagoya, Japan

\begin{abstract}
The population of patients with renal failure requiring long-term dialysis is large and growing. Over the last 6 years, we have done 55 operations among 42 patients treated with chronic hemodialysis. Surgical disorders in these patients were carpal tunnel syndrome (20 cases), femoral head necrosis ( 7 cases), medial fracture of the femoral neck ( 7 cases) and others ( 8 cases). We report our experiences concerning the care given before, during and after surgery to patients on maintenance hemodialysis. We emphasize the importance of the complications of hyperkalemia, sepsis, hemorrhage, anemia and delayed wound healing. There must be careful observation for these complications and aggressive nutritional, hematologic and metabolic intervention to avoid preventable operative complications. Using FOY ${ }^{\circledR}$, we can reopen hemodialysis on the first postoperative day. Intravenous regional anesthesia is useful for the operation of an upper extremity.
\end{abstract}

\section{諸 \\ 言}

現在 5 万人以上の血液透析患者がおり, 総数の増加 とともに長期透析例も増加し整形外科的合併症で手術 を行なう機会も多くなったが, 通常の手術と異なり注 意点, 問題点も少なくない. 我々の経験を文献的考察 を加えて報告する。

\section{症例}

1982年より現在までに我々が手術を行なった透析患 者は表 1 (下肢手術症例), 表 2 (上肢手術症例) のご とくである.手根管症候群が最多で 20 人に対し 24 回手 術を施行した。

(i)下肢及び肩手術症例について

男 10 人，女 11 人計 21 人に対し 30 回の手術を施行した。 大腿骨頭壊死 11 関節，頝部内側骨折が 7 関節と多く, 手術々式も THR 12 関節, FHR 9 関節と股関節に対
する手術が大部分を支めた．感染例 2 例はいずれも結 核であった。2 回以上の多数回手術症例が 7 例と全体 の 3 割を支めたのは骨壊死症例が多かったためと思わ れる。麻酔は全麻 22 回, 硬膜外 8 回であった。

(ii)肩を除く上肢手術症例について

稀な上腕三頭筋腱皮下断裂の症例以外はすべて手根 管症候群例であり 20 人に対し25手，24回の手術を施行 した。合併症としてバネ指 4 例 6 指, 时部管症候群 1 例を認め，腱鞘切除と king 法を追加した。また 4 例 に母指対立筋形成術を追加した。術前透析期間は 7 年 10 ケ月より 17 年 9 ケ月, 平均 12 年 5 ケ月と長く全体の 約 8 割が透析 10 年以上の症例であった.

\section{透析患者の術前管理}

透析患者はさまざまな異常を有しているが，特に手 術に関し問題となる病態は(1)出血傾向 (2)高 $\mathrm{K}^{+}$血症と 湓水(3)免疫不全による易感染性(4)創傷治癒の遅延(5)貧 
表 1 下肢手術症例

\begin{tabular}{|c|c|c|c|c|c|c|}
\hline Case & 性 & $\begin{array}{l}\text { 手術時 } \\
\text { 年歯 }\end{array}$ & 原 疾 患 & 手術々式 & 麻 酔 & $\begin{array}{l}\text { 手 術 前 } \\
\text { 透析期間 }\end{array}$ \\
\hline \multirow[t]{2}{*}{1} & 男 & 45 & 両大腿骨頭壊死 & Lt T.H.R. & 全 麻 & 10年 1 ケ月 \\
\hline & & & & Rt F.H.R. & 全 麻 & 10年 3 ケ月 \\
\hline \multirow[t]{3}{*}{$* 2$} & 男 & 36 & 両大腿骨頭壊死 & Lt T.H.R. (revision) & 全 麻 & 6 年 7 ケ月 \\
\hline & & 39 & 右大腿骨顆部壊死 & Rt T.K.R. & 硬膜外 & 9 年 \\
\hline & & 39 & 右大腿骨骨折 & 骨移植, プレート固定 & 全 麻 & 9 年 3 ケ月 \\
\hline \multirow[t]{2}{*}{3} & 女 & 26 & 両大腿骨頭壊死 & Rt F.H.R. & 全 麻 & 7 年 2 ケ月 \\
\hline & & & & Lt T.H.R. & 全 麻 & 7 年 9 ケ月 \\
\hline 4 & 男 & 64 & 右大腿骨頭壊死 & Rt F.H.R. & 全 麻 & 6 年 2 ケ月 \\
\hline \multirow[t]{2}{*}{5} & 男 & 59 & 両大腿骨頭壊死 & Rt T.H.R. & 全 麻 & 4 年 \\
\hline & & 60 & & Lt T.H.R. & 全 麻 & 5 年 \\
\hline \multirow[t]{2}{*}{ () 6} & 男 & 37 & 両大腿骨頭壊死 & Lt T.H.R. & 全 麻 & 3 年 3 ケ月 \\
\hline & & & & Rt T.H.R. & 全 麻 & 3 年 6 ケ月 \\
\hline 7 & 男 & 55 & 左大腿骨頭壊死 & Lt T.H.R. & 全 麻 & 2 年 8 ケ月 \\
\hline 8 & 男 & 64 & 右大腿頸部内側骨折 & Rt F.H.R. & 全 麻 & 17 年 \\
\hline 9 & 女 & 67 & 左大腿頸部内側骨折 & Lt F.H.R. & 全 麻 & 14年 \\
\hline 10 & 女 & 59 & 左大腿頸部内側骨折 & Lt F.H.R. & 全 麻 & 13年 \\
\hline 11 & 男 & 58 & 左大腿頸部内側骨折 & Lt F.H.R. & 硬膜外 & 11年 5 ケ月 \\
\hline 12 & 男 & 62 & 左大腿頸部内側骨折 & Lt T.H.R. & 全 麻 & 11年 \\
\hline 13 & 女 & 43 & 右大腿頸部内側骨折 & Rt F.H.R. & 全 麻 & 10年 2 ケ月 \\
\hline 14 & 女 & 76 & 左大腿頸部内側骨折 & Lt F. H.R. & 全 麻 & 3 ケ月 \\
\hline 15 & 女 & 38 & R A & Rt T.H.R. & 全 麻 & 10年 4 ケ月 \\
\hline \multirow[t]{2}{*}{16} & 女 & 49 & R A & Lt T.H.R. & 硬膜外 & 10 ケ月 \\
\hline & & 49 & & bil T.K.R. & 硬膜外 & 1 年 \\
\hline 17 & 女 & 40 & 左変股症 & Lt T.H.R. & 全 麻 & 10年 5 ケ月 \\
\hline 18 & 男 & 63 & 左大腿転子間骨折 & Ender nail & 硬膜外 & 5 年 9 ケ月 \\
\hline 19 & 女 & 60 & 左脛骨骨髄炎 (結核性) & 病巣搔爬 & 硬膜外 & 10年 5 ケ月 \\
\hline \multirow[t]{2}{*}{20} & 女 & 63 & 左足糖尿病性壊死 & 左下腿切断 & 硬膜外 & 5 ケ月 \\
\hline & & & & 左大腿切断 & 硬膜外 & 6 ケ月 \\
\hline
\end{tabular}

* 8 年前に Rt T.H.R. 6 年前に Lt T. H. R. 既術

(C) CAPD

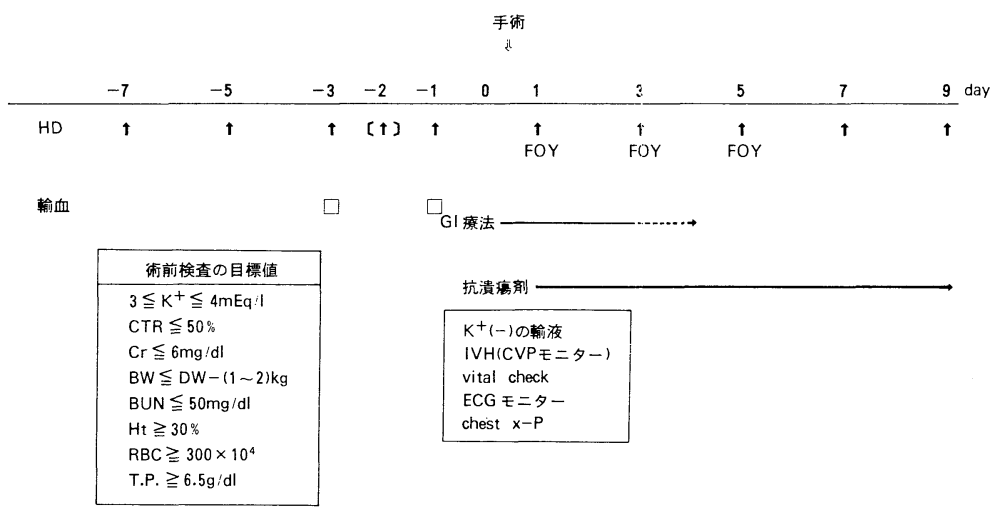

図 1 透析患者における手術 
表 2 上肢手術症例

\begin{tabular}{|c|c|c|c|c|c|c|}
\hline Case & 性 & $\begin{array}{c}\text { 手術時 } \\
\text { 年齢 }\end{array}$ & \multicolumn{1}{|c|}{ 原 疾 患 } & 手術 々式 & 麻 酔 & $\begin{array}{c}\text { 手術 前 } \\
\text { 透析期間 }\end{array}$ \\
\hline 1 & 女 & 49 & $\begin{array}{r}\text { 右化膿性肩関節炎 } \\
\text { (結核性) }\end{array}$ & $\begin{array}{l}\text { 病巣搔爬 } \\
\text { 右肩関節固定 }\end{array}$ & $\begin{array}{l}\text { 全 麻 } \\
\text { 全 麻 }\end{array}$ & $\begin{array}{l}7 \text { 年 } 8 \text { ケ月 } \\
8 \text { 年 } 3 \text { ケ月 }\end{array}$ \\
2 & 男 & 47 & 右上腕三頭筋腱皮下断裂 & 腱縫合術 & 腋窩ブロック & 9 年10 月月 \\
\hline
\end{tabular}

手根管症候群手術症例

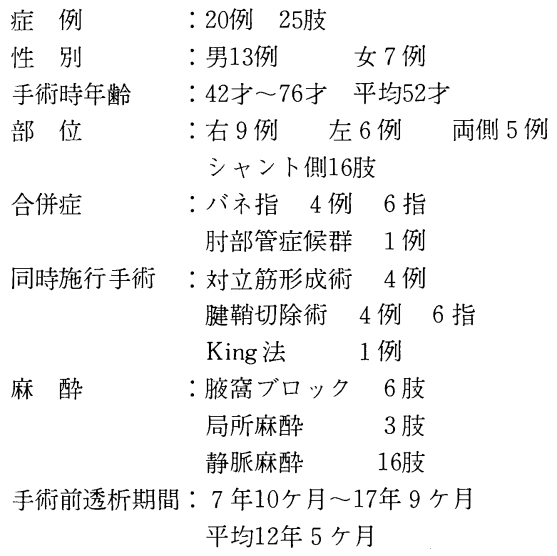

血(6)低栄養状態(7)薬物代謝・排泄異常であり，常にこ れらのことを念頭において対処すべきである.

一般に整形外科領域においては緊急手術をせざるを 得ない場合は稀であり，術前に患者の状態を十分把握 し合併症を改善して手術にのぞむべきである．我々は 術前に改善すべき項目とコントロール目標値を図 1 の ごとく設定している ${ }^{1) 21}$.

特に注意すべきは $\mathrm{K}^{+}$のコントロールである，透析 患者は $(1) \mathrm{K}^{+}$排泄の低下 $(2)$ 手術侵襲による異化作用 (3)アシドーシスによる細胞内より細胞外への $\mathrm{K}^{+}$の移行 (4)異化作用による細胞の破壊(5)輸血による $\mathrm{K}^{+}$の上昇 等により高 $\mathrm{K}^{+}$血症におちいりやすい ${ }^{1)}$. 従って術前の 充分かつ頻回の透析, イオン交換樹脂の投与, glucoseinsuline 療法を行ない $3 \leqq \mathrm{~K}^{+} \leqq 4 \mathrm{mEq} / \mathrm{l}$ の範囲内にコ ントロールしている. 溢水, 高窒素血症, 代謝性アシ ドーシスの是正もコントロール值を維持するため必要 なら連日でも透析を行なうべきである.

貧血の是正は，透析患者の $85 \%$ がへモグロビン $8 \mathrm{~g} / \mathrm{dl}$ 以下であり ${ }^{3 !}$, 過度の輸血は血清カリウムを上昇させ 末梢循環を悪化させるのみでなく, 循環血液量増加の
ため心不全をおこす危険すらあるので，術前輸血は透 析を利用し必要最小限にとどめるべきである.

\section{透析患者の麻酔について}

硬膜外，背椎麻酔は容易で種々の薬剤を使用しない 利点はあるが，血圧コントロールがむずかしく穿刺に より硬膜外血腫を作り，背髄圧迫症状をおこす危険が あるので出血傾向の強い患者には禁忌であり，全身麻 酔の方が安全である場合が多い。

手根管症候群に対する麻酔は，初期は腋窩ブロック を行なっていたが，血腫形成の危険があり手根管開放 術のみでは手術時間は20分程で，対立筋形成とバネ指 に対する処置を加えても 1 時間以内に終了するので最 近は $1 \%$ キシロカイン $20 \mathrm{ml}$ を用いた静脈内局所麻酔を 行なっている.この方法は患者の苦痛も軽く簡単で, ターニケットを使用するため無血野で手術が行なえる 反面，患肢にシャントがある場合シャントのトラブル 発生が問題となる. 我々は 1 例にのみ clotによるシ ヤント閉塞を経験した。ヘパリン等の抗凝固剤の血管 内投与は術後の創出血の危険があるため行なっていな 
いが，エスマルヒを巻く際シャント部をさける，ター ニケットを用いずエスマルヒのみでシャント部より末 梢のみ駆血する，手術時間を短かくする，頻回のシャ ントトラブルの既往のある症例は他の方法を用いる等 の注意が必要である.

\section{術中の注意点}

術中操作は術野の清潔保持, 組織に対する愛護的操 作を心がけることは当然であるが，止血はそのつど丹 念にかつ確実に行なうべきであり，安易な電気メスに よる止血はひかえ結紮により確実に止血すべきである. 術後血腫はその吸収により $\mathrm{K}^{+}$を上昇させ感染源とも なりうるのでサクションドレーンを留置すべきである. 上肢の手術においても止血は必ずターニケットを off とした後に確認し，特にシャント側の手術では静脈圧 が高く出血しやすいので止血は徽底的に行なうべきで ある.また皮膚血行は必らずしも良好ではないので, 三角皮弁の先端等は壊死に陷いりやすく, 皮切のデザ インにも十分配慮すべきである。

\section{抗生剤と術後管理}

抗生剤は起炎菌にあったものを使用するのが前提で あるが，一般には安全域が広いペニシリン系や七ファ 厶系が選択される. 1 日 1 回，透析日は透析後に投与 しているが，過量投与により下痢と出血傾向をおこす 危険があり使用薬剤の特性を十分理解して使用すべき である。

術後管理は通常の vital sign チェックの他, 血液ガ ス分析により換気状態とアシドーシスを改善し，血清 電解質をチェックするとともに心電罒モ二ターにより $\mathrm{K}^{+}$值を監視し, 胸部レントゲンで溢水の有無を確認 し中心静脈圧測定により輸液量を決定する. さて問題となるのは透析の再開時期である. 全身状
態改善のためには早期の透析再開が望まれるが，透析 時使用するへパリンによる手術創内の再出血が危惧さ れるため一般には透析再開日の延長や減へパリン療法 が行なわれることが多いが，当院は手根管症候群例以 外はほとんど FOY ${ }^{\circledR}$ 使用により手術翌日より透析を再 開し再出血を防いでいる ${ }^{4)}$. ドレーン抜去は排液増加 のないことが前提であるが全例手術翌々日には抜去可 能であった。

術後合併症として危険なのは消化管出血である.我 々は術後 1 週より始まった出血性胃炎が止血されず多 臓器不全となり死亡した 1 例を経験しており, 予防的 に抗潰瘍剤投与は行なった方がよいと考えている.

\section{ま と め}

1. 透析患者 42 人に対し 55 回の手術を施行した。 内, 20人24回の手術は手根管症候群であった。

2. 透析患者は出血傾向, 易感染性, 貧血, 創傷治愈 の遅延, 薬物代謝・排泄異常等の問題を有している ことを念頭において対応すべきである.

3. 特に $\mathrm{K}^{+}$のコントロール, 輸液量, 術中の止血と 愛護的操作が重要である.

4. 術後出血予防には FOY 透析が効果的であった.

5. 手根管症候群の手術には静脈内局所麻酔が有用で あった。

\section{参考 文 献}

1）寺岡慧ほか：透析患者の外科手術. 日本臨床特別号 : 612-618, 1985.

2）千葉省三：貧血. 臨床透析, 2 : 36-37, 1986.

3）太田和夫：腎不全患者の外科手術における問題点と 対策. 今日の臨床外科, $9: 129-144,1980$.

4）稲垣豊ほか：局所抗凝固療法としての FOY 透析の 試み。現代医療, $14 ： 543-548,1982$. 